\title{
Wolfram Walter Swoboda
}

Dr. Wolfram Walter Swoboda, a specialist in the history of science in Central Europe, passed away on February 1, 1982, at the age of 38. Born in Łódź, Poland, Wolf studied at the University of Pittsburgh and the University of Vienna. He served on the faculties of the University of Pittsburgh, Karl-Franzens University in Graz, and University College (London).

His dissertation dealt with Ernst Mach's early intellectual development; it focused on Mach's introduction to medicine and physiology and the importance of these disciplines in forming Mach's later approach to the methodology of physics. An abbreviated version was published under the title, "Physiology, Psychophysics and the Origins of Ernst Mach's Empiriocriticism," in the Rivista di Filosofia. His wide-ranging interests were reflected in his published articles, which included topics as diverse as the views of Marx and Engels on the nationalities question in the Austrian monarchy, Richard Avenarius, and the problem of interdisciplinarity in education. His last major publication involved co-editing an annotated edition of the letters of Ernst Wilhelm von Brücke to Emil du BoisReymond.

University of Pittsburgh

Bob SUPANSIC 